\title{
Türkiye’de Vergi Esnekliği ve Kamu Kesimi Büyüklüğü İlişkisi'
}

Gülsüm GÜRLER-HAZMAN (https://orcid.org/0000-0002-9953-4330), Afyon Kocatepe University, Turkey; gghazman@aku.edu.tr

Pinar Bengi KAYA (https://orcid.org/0000-0001-9560-4584), Afyon Kocatepe University, Turkey; pbkoklu@aku.edu.tr

\section{The Relationship Between Tax Elasticity and The Size of Public Sector in Turkey $^{2}$}

\begin{abstract}
Tax elasticity, calculated by dividing the proportional change in tax revenues by the proportional change in the tax base, helps to provide automatic stability in public revenues. In this study, we aimed to determine the relationship between the total tax revenue elasticity and the size of the public sector for the period 1990-2019 in Turkey, there is no causality in the short term, but oneway causality from the size of the public sector to tax elasticity was determined in the long term. Also, population change, and economic growth affect the size of the public sector because one-way causality towards the size of the public sector has been determined.
\end{abstract}

Keywords $\quad$ : Tax Elasticity, Public Sector Size, Public Expenditures.

JEL Classification Codes : $\quad$ H2, H21, H69.

Öz

Vergi gelirlerindeki oransal değişimin, vergi matrahındaki oransal değişime bölünmesi ile hesaplanan vergi esnekliği, kamu gelirlerinde otomatik istikrar sağlanmaya yardımcı olur. Türkiye'de 1990-2019 dönemi için toplam vergi gelirleri esnekliği ile kamu kesimi büyüklüğü arasındaki ilişkinin tespitini amaçladığımız çalışmada, kısa dönemde bir nedensellik tespit edilmemiş, ancak uzun dönemde kamu kesimi büyüklüğünden vergi esnekliğine doğru tek yönlü nedensellik tespit edilmiştir. Ayrıca Türkiye'de nüfus değişimi ve ekonomik büyüme kamu kesimi payını etkilemekte çünkü kamu kesimi büyüklügüne doğru tek yönlü bir nedensellik tespit edilmiştir.

Anahtar Sözcükler $\quad$ : Vergi Esnekliği, Kamu Kesimi Büyüklüğü, Kamu Harcamaları.

1 Söz konusu makale çalışması Afyon Kocatepe Üniversitesi Bilimsel Araştırma Projeleri Komisyonunca kabul edilen 20.SOS.BIL.01 no'lu proje kapsaminda desteklenmektedir.

2 This study was supported by the Afyon Kocatepe University Research Projects Commission (project number: 20.SOS.BIL.01). 


\section{Giriş}

Vergilemeden beklenen amaç ve fonksiyonlar, zamanla iktisadi ve toplumsal hayattaki değişimlere bağlı olarak değişim göstermiştir. Tüm değişimlere rağmen mali amaç olarak ifade edilen kamusal mal ve hizmetlerin finansmanını sağlama amacı günümüzde de vergilemenin en önemli amacı olma özelliğini korumaktadır. Söz konusu amaç ile ilgili olan vergilemede etkinlik kavramı, ekonomide refah kaybı yaratmayan, eğer yaratıyorsa kaybın minimum olduğu ve aynı zamanda yüksek vergi hasılatı sağlayan vergileme ile ilişkilidir. Vergilemede etkinlik devletin kamu harcamalarını karşılayabilmek adına optimal düzeyde gelir sağlama amacına hizmet etmektedir (Güler \& Karaca, 2017: 166).

Vergilemede etkinliğin ölçülmesinde ve uygulamaya konulması planlanan veya konulan vergi politikalarının etkinliğinin tespiti noktasında vergi esnekliği kavramı çok önemlidir. Çünkü vergi esnekliği, vergi gelirlerinin milli gelire olan duyarlılığını ölçmek için kullanılan bir parametre olup aynı zamanda vergi sisteminin otomatik büyüme potansiyelini de göstermektedir. Bir vergi sisteminin esnekliği ne kadar yüksek olursa, vergi gelirleri ulusal gelirdeki büyümeye o kadar duyarlı olacaktır.

Vergi esnekliğinin hesaplanması, vergi yapısının dönüşümü hakkında bilgi vermekle birlikte vergi sisteminin konjonktüre olan duyarlılığını ve dolayısıyla vergi sisteminin otomatik stabilizatör olma özelliğini de etkilediği için önemlidir. Vergi esnekliği, vergi gelirlerinin kamu harcamalarını karşılama gücü hakkında da bilgiler vermektedir. Esnek bir vergi sistemi demek milli gelirde meydana gelen artıştan daha yüksek düzeyde vergi hasılatında bir artış meydana gelmesi demektir. Esnek bir vergi sistemine sahip ülkeler milli gelirlerindeki büyümeye duyarlı olacaklardır ve bu durumda da gelirdeki artış kamu harcamalarını artırıcı yönde etki yapacaktır. Sonuç olarak gelirdeki artış sayesinde daha fazla kamu harcaması gerçekleştirebilecektir. Literatürde, vergi sisteminin esnekliğinin ülkelerin kamu kesimi büyüklüğü ile olan ilişkisinin düzeyine yönelik az sayıda somut bulguya rastlanmaktadır. Bu çalışmanın amacı, "Ekonomide kamu kesiminin payının artması ya da azalması, vergi sisteminin esnekliğini ne düzeyde ilişkidir?” sorusundan hareketle, vergi gelirlerinin esnekliği ile kamu kesimi büyüklüğü arasındaki ilişkinin tespit edilmesidir.

Kamu kesimi büyüklüğünün hesaplanmasında en çok tercih edilen yöntem olan kamu harcamalarının GSYH'ye oranında kullanılan kamu harcamaları, kamu gelirlerini karşılama kabiliyeti hakkında yorum yapmamızı sağlamaktadır (Güler, 2017: 163). Dolayısıyla bu çalışmada kamu kesimi büyüklüğü olarak kamu harcamalarının GSYH payı dikkate alınacaktır. Çalışmada kamu kesimi büyüklüğü ile toplam vergi gelirleri esnekliği arasındaki kısa ve uzun dönemli nedensellik ilişkisi Türkiye açısından 1990-2019 dönemi için ele alınacaktır. 1990-2019 yılları arasında Türkiye'de vergi gelirlerinin esnekliği ile kamu kesimi büyüklüğü arasındaki ilişkinin tespit edilmesini amaçlayan bu çalışmada, ekonomide kamu kesimi payının artması ya da azalmasının vergi gelirlerinin konjonktüre olan duyarlılığını diğer bir ifadeyle vergi sisteminin otomatik stabilizatör olma özelliğini etkileyip etkilemediği incelenmiştir. Söz konusu iki değişken nedensellik testi ile sınanırken, 
literatürde yer alan çalışmalardan yola çıkarak, diğer kontrol değişkenler nüfus değişimi ve ekonomik büyüme olarak belirlenmiştir.

\section{Vergi Esnekliği Kavramı}

Uygulanan maliye politikalarının etkinliğinin ölçülmesi bakımından vergi gelirlerinin, milli gelirdeki değişikliğe verdiği tepkinin tahmin edilmesi son derece önemlidir (Boschi \& d'Addona, 2019: 2). Tepkinin tahmin edilmesi kadar, söz konusu tepkinin milli gelirdeki değişmelerle birlikte otomatik olarak mı gerçekleştiği yoksa otomatik değişimlere ek olarak devlet tarafından alınan tedbirler neticesinde mi gerçekleştiğinin tespit edilmesi son derece önemlidir.

Vergi sisteminde etkinliğin ölçülmesinde kullanılan vergi esnekliği, vergi gelirlerinin milli gelirdeki değişmelere olan duyarlılığını ifade etmek için kullanılan bir kavramdır. Söz konusu kavramı matematiksel olarak ifade etmek gerekirse, vergi gelirlerindeki yüzde değişimin vergi matrahındaki yüzde değişime bölünmesidir. Devlet tarafından vergi oranlarında yapılan bir değişiklik gibi ihtiyari bir değişikliğin olmadığı varsayılarak hesaplandığı için vergi esnekliği varsayımsal bir yapıdadır. Neticede de vergi sisteminin otomatik büyüme potansiyelini göstermektedir (Acheson et al., 2017: 2).

Vergi esnekliğinin tahmin edilmesi sadece ülkemizde değil tüm dünyada çok sayıda çalışmaya konu olmuştur. Her ekonomideki parasal ve mali otoriteler için vergi esnekliğinin ölçülmesinin önemli nedenleri vardır. Bu nedenlerden ilki esnekliğin makroekonomik tahminlere dayandırılarak hükümet gelirlerinin tahmin edilmesi için taşıdığı önemdir. Eğer tahminlerde ciddi yanılmalar ortaya çıkarsa bu durum özellikle orta vadeli bütçe hedeflerinden sapmalara sebebiyet verebilir. İkinci neden olarak ise otomatik stabilizatörlerin ve ihtiyari tedbirlerin etkilerini ayrıştırabilmektir (Havranek et al., 2016: 5866). Vergi gelirlerinin milli gelire olan duyarlılığını ölçmede kullanılan ve standart bir parametre olan vergi esnekliği gelecek yıl mali yıl bütçesinin hazırlanmasında önemli bir unsurdur. Ayrıca vergi esnekliği bütçe dengelerinin döngüsel olarak ayarlanmasında da önemli bir role sahiptir. Vergi esnekliğinin doğru tespit edilmesinin önemi 2000'li yılların ortasında daha fazla artmıştır. Bunun sebebi ise ekonomik büyüme oranlarının standart esneklik hesaplamaları ile birleştirilerek hesaplanabilmesidir (Wolswjik, 2007: 7).

Vergi esnekliğinin tüm vergi sistemi için hesaplanması mümkün iken, ayrı ayrı her bir vergi türü için de hesaplanması mümkündür. Tüm vergi sistemi için vergi esnekliği denklem 1'de; vergi türleri için hesaplanan vergi esnekliği ise denklem 2'de gösterilmiştir (Mansfield, 1972: 426):

$$
\begin{array}{ll}
\mathrm{ET}_{\mathrm{t}} \mathrm{y}=\frac{\Delta T t}{\Delta Y} \times \frac{Y}{T t} & \text { (denklem 1) } \\
\mathrm{ET}_{\mathrm{t} \mathrm{y}}=\frac{T 1}{T t}\left[\frac{\Delta T 1}{\Delta Y} \times \frac{\mathrm{Y}}{\mathrm{T} 1}\right]+\ldots \ldots .+\frac{T k}{T t}\left[\frac{\Delta T k}{\Delta Y} \mathrm{x} \frac{Y}{T k}\right]+\ldots \ldots+\frac{T n}{T t}\left[\frac{\Delta T n}{\Delta Y} \mathrm{x} \frac{Y}{T n}\right] & \text { (denklem 2) }
\end{array}
$$

$\mathrm{ET}_{\mathrm{ty}} \mathrm{y}$ Toplam vergi gelirlerinin esnekliği, 
$\mathrm{T}_{\mathrm{t}}$ : Toplam vergi geliri,

$\Delta \mathrm{T}_{\mathrm{t}}$ : Vergi gelirlerindeki yüzde değişim (otomatik değişim),

Y: GSYH,

$\Delta Y$ : GSYH'deki yüzde değişim.

Vergi esnekliği hem kısa dönem için hem de uzun dönem için hesaplanabilmektedir. Her iki dönem için hesaplamanın amacı farklıdır. Kısa dönem esneklik ile hedeflenen konjonktür dönemlerinde GSYH'deki dalgalanmaların vergi gelirlerindeki değişikliğinin belirlenmesi iken, uzun dönem hesaplanan esneklik ile GSYH'deki artışların zaman içerisinde vergi gelirlerinde nasıl büyüme meydana getirdiğinin tespitidir. Hesaplanan esneklik katsayıları farklı değerler alabilmektedir. Söz konusu katsayının alabileceği değerler 0 veya 1 olabileceği gibi 1 'den büyük veyahut küçük de olabilir. Katsayının 1'den büyük olması vergi sisteminin esnek bir yapıda oluğunun göstergesidir. Ayrıca katsayının 1 'den büyük olması konjonktürün canlanma dönemlerinde yüksek gelir elde edildiği, daralma dönemlerinde ise daha az gelir edildiği ve vergi gelirlerindeki artışın GSYH'deki artıştan daha fazla olduğu anlamına gelmektedir. Katsayının 1'den küçük olması vergi gelirlerindeki artışın GSYH'deki artışın gerisinde kaldığının ve esnek olmayan bir vergi sisteminin varlığının göstergesidir. Esneklik katsayısının 1 olması vergi sisteminin birim esnek bir yapıya sahip olduğu diğer bir ifade ile vergi gelirlerindeki artış ile GSYH'deki artışın eşit ölçüde olduğunu; katsayının 0 olması ise vergi gelirleri ile GSYH arasında herhangi bir ilişkinin söz konusu olmadığını göstermektedir.

Vergi sisteminin esnek olması arzu edilen bir durumdur. Çünkü konjonktürel değişimlere karşı vergi sisteminin esnekliği gelir istikrarını sağlamakta ve vergi sisteminde düzenleme yapma ihtiyacını azaltmaktadır (Haughton, 1998: 3). Ayrıca esnek bir vergi sistemine sahip devletlerde borçlanma ve harcama planlamaları da kolaylaşmaktadır.

Tüm vergi sistemlerinde olduğu gibi Türk vergi sistemini esneklik açısından değerlendirmek gerekirse vergi tarifelerine ve vergi türlerine göre farklılık göstermektedir. Vergileri konularına göre değerlendirmek gerekirse artan oranlı gelir vergisi esnek yapıdadır; düz oranlı kurumlar vergisinin esnekliği ise bire eşittir. Vergi türleri arasında farklılık göstermekle birlikte harcamalar üzerinden alınan vergiler dikkate alındığında söz konusu vergilerin esnekliği düşük, servet üzerinden alınan vergilerin ise nötrdür. Çalışma kapsamında değerlendirme yapabilmek adına aşağıdaki tabloda genel bütçe vergi gelirleri, gelir vergisi kurumlar vergisi ve katma değer vergisinin esnekliğine yer verilmiştir. 
Tablo: 1

Genel Bütçe Vergi Gelirleri, Gelir Vergisi, Kurumlar Vergisi ve Katma Değer Vergisi Tahsilatının GSYH'ye (2009 Bazlı) Göre Esneklikleri (2000-2019)

\begin{tabular}{|c|c|c|c|c|}
\hline YILLAR & $\begin{array}{c}\text { GENEL BÜTÇE } \\
\text { VERGI GELI RLERi }\end{array}$ & $\begin{array}{c}\text { GELI R } \\
\text { VERGísi }\end{array}$ & $\begin{array}{l}\text { KURUMLAR } \\
\text { VERGÍSi }\end{array}$ & $\begin{array}{c}\text { KATMA DEGER } \\
\text { VERGISi }\end{array}$ \\
\hline 2000 & 1,32 & 0,44 & 0,88 & 1,71 \\
\hline 2001 & 1,13 & 1,97 & 1,28 & 1,11 \\
\hline 2002 & 1,08 & 0,40 & 1,11 & 1,38 \\
\hline 2003 & 1,36 & 0,81 & 1,82 & 1,08 \\
\hline 2004 & 0,85 & 0,66 & 0,48 & 1,16 \\
\hline 2005 & 1,08 & 0,97 & 1,13 & 0,76 \\
\hline 2006 & 1,58 & 1,06 & $-0,49$ & 1,17 \\
\hline 2007 & 1,13 & 1,73 & 2,27 & 0,81 \\
\hline 2008 & 0,85 & 1,29 & 1,44 & 0,64 \\
\hline 2009 & 9,24 & 9,91 & 30,37 & 0,39 \\
\hline 2010 & 1,25 & 0,46 & 0,65 & 1,60 \\
\hline 2011 & 1,02 & 1,05 & 1,37 & 1,30 \\
\hline 2012 & 0,92 & 1,30 & 0,78 & 0,63 \\
\hline 2013 & 1,04 & 0,85 & $-0,14$ & 1,31 \\
\hline 2014 & 0,73 & 1,23 & 0,93 & 0,41 \\
\hline 2015 & 1,10 & 1,09 & 0,36 & 1,24 \\
\hline 2016 & 1,18 & 1,48 & 2,28 & 0,83 \\
\hline 2017 & 0,94 & 0,85 & 1,21 & 1,16 \\
\hline 2018 & 0,90 & 1,10 & 2,28 & 1,07 \\
\hline 2019 & 0,74 & 1,24 & 0,27 & 0,52 \\
\hline
\end{tabular}

Kaynak: Gelir İdaresi Başkanlı̆̆ı'nın resmi internet sayfasından temin edilmiştir ${ }^{3}$.

Tablo incelendiğinde, vergi esnekliklerinde genel olarak dalgalı bir seyrin olduğu görülmektedir. Katma değer vergisi hariç diğer vergilerde ve toplam vergi gelirlerinin esnekliğinde 2009 yılındaki yüksek düzeyler dikkat çekmektedir. Özellikle kurumlar vergisi için 30,37 düzeyindeki esneklik oldukça fazladır. Söz konusu oranları yorumlamak gerekirse GSYH'deki bir birimlik artış toplam vergi gelirleri tahsilatında 9,24 gelir vergisi tahsilatında 9,91 ve kurumlar vergisi gelirlerinde ise 30,37 oranında bir artış meydana getirmiştir. Bunun nedeni 2008 yılında ortaya çıkan ve tüm dünyayı etkileyen küresel krizin etkisi olduğu söylenebilir. Kurumlar vergisi esnekliğinin bu denli yüksek olmasının sebebi ise küresel krizin etkisi ile GSYH'de düşüş yaşanması ve buna karşılık kurumlar vergisi tahsilat rakamlarında önemli ölçüde farklılık olmaması olarak açıklanabilir.

\section{Kamu Kesimi Büyüklüğü ve Ölçülmesi}

Devlete olan ihtiyacın ortaya çıktığı tarihten günümüze kadar, devlete hangi tür görevler yükleneceği ve devletin sınırlarının ne olacağı tartışma konusu olmuştur. Bazı dönemlerde devlete yüklenen görevler artarken bazı dönemlerde ise azalmıştır. Bu görevlerdeki artış ve azalışta ülkelerin ekonomik, sosyal ve siyasal yapıları etkin rol oynamıştır. Son yıllarda ise hâkim olan devlet anlayışı ülkelerin kalkınma seviyeleri göz önünde tutularak minimal devletten sosyal refah devletine doğru bir geçişin olduğu yönündedir. Bu değişim ile birlikte devlet, toplumun huzur ve refahını gözetme amacıyla

3 Genel Bütçe Vergi Gelirlerine ilişkin esneklik katsayıları tarafimızca hesaplanmıştır. 
milli ekonomi içerisindeki payını artırmakta ve özel kesime yol gösterici bir tutum izleyerek sosyal alanlarda toplumun refahını artıran harcamalarda bulunmaktadır. Bu durumda devletin kamusal hizmet üretmesi ve sosyal hayatta etkin konuma gelmesi, kamu kesiminin payını daha da artırmıştır (Sandalcı \& Sandalcı, 2016: 412).

Kamu kesiminin iktisadi hayat içerisindeki varlık sebebi değerlendirildiğinde, asıl sebebin piyasa ekonomisi ile rekabet olmadığı, sınırsız insan ihtiyaçlarının kıt kaynaklar ile giderilmesi sürecinde piyasa ekonomisine işlerlik kazandırmak olduğu görülmektedir. Ancak klasik devlet anlayışı diğer bir ifade ile devletin ekonomiye müdahalesinin sınırlı tutulması gerektiği görüşünden günümüze kamu kesiminin iktisadi hayat içerisinde hangi ölçekte yer alacağı, mal ve hizmetlerin hangisinin piyasa eliyle hangisinin kamu kesimi tarafından üretileceğinin tartışması devam etmektedir. $\mathrm{Bu}$ tartışma kamu kesiminin sınırlarının ne olacağının belirlenmesi açısından da önemlidir. Bir ülkedeki kamu kesiminin büyüklüğü, yapısı ve bileşimi ülkeden ülkeye farklılık göstermektedir. Bu farklılık ülkelerin tarihsel, siyasal ve ekonomik faktörlerinden kaynaklanmaktadır. Tüm tartışmalara rağmen hem gelişmiş hem de gelişmekte olan ülkelerde ülke ekonomisi içerisinde geçmişten günümüze kadar kamu kesiminin büyüklüğü artış trendi içerisinde olduğu bilinmektedir (Ertekin, 2020: 141-142).

Kamu kesiminin ekonomideki rolü ve ağırlığının ne ölçüde olması gerektiği iktisatçılar arasında ciddi tartışma konusu olmuştur. Başlıca iktisat okullarını bu kapsamda ele almak gerekirse ilk olarak klasik liberal düşünceye göre kamu kesiminin ekonomideki rolü minimal olmalıdır. Kamu kesimi sadece adalet, güvenlik gibi tam kamusal mal ve hizmetleri sunarken ekonomiye müdahalede bulunmalıdır. Çünkü Klasiklere göre ekonomi zaten tam istihdam denge düzeyindedir ve ekonomik istikrarsızlıkların asıl sebebi kamu harcamaları ve vergiler gibi maliye politikası araçları ile yapılan müdahalelerdir. Keynesyen iktisadi düşünceye göre ise, kamu kesimi müdahaleci devlet anlayışı ile ekonomide varlığını sürdürmelidir. Bu düşünceye göre kamu kesiminin ekonomi içerisindeki payı artmalıdır. Neo-Klasik düşünceye göre ise kamu kesimi sadece bazı sebeplerle ekonomiye müdahalede bulunabilir. Bu sebepler gelir dağılımında adalet ve kaynak dağılımında etkinliğin sağlanmasıdır.

Kamu kesiminin bir ekonomideki büyüklügüüü ölçerken kamu harcamaları, vergiler, kamu yatırım harcamaları ve kamu istihdamı gibi çeşitli unsurlar bulunmaktadır. Bu unsurlardan yola çıkarak Ekonomik Özgürlükler Endeksi (Economic Freedom of the World: EFW) oluşturulurken "kamu kesiminin büyüklüğü”nü ölçmek için kullanılan göstergeler aşağıdaki gibidir (Acar, 2010: 11):

- Toplam tüketim içinde kamunun tüketimi,

- GSYH’nin yüzdesi olarak transfer harcamaları ve sübvansiyonlar,

- Toplam yatırım harcamaları içinde kamu yatırım harcamalarının payı,

- Gelirlerden ve ücretlerden alınan vergi oranı ve bu oranların uygulandığı gelir ve ücret eşiği. 
Bir ülkede kamu kesiminin büyüklüğünü ölçmek için çeşitli yöntemler bulunmaktadır. $\mathrm{Bu}$ yöntemler ülkeler arası karşılaştırma yapabilmek adına oldukça önemlidir. Yöntemlerden en çok bilinen ve yaygın olarak da kullanılan kamu harcamalarının GSYH'ye oranlanmasıdır (Kirmanoğlu, 2014: 41). Hesaplamalar yapılırken GSMH'den ziyade GSYH tercih edilir. Bunun sebebi GSMH ile GSYH arasındaki fark ile açıklanmaktadır ve en önemli fark üretimin sınırlarıdır. GSYH, yerli ya da yabancı şirketler tarafından ülke sınırları içerisinde üretilen tüm mal ve hizmetleri hesaba alır. Diğer ülkelerde üretilen malları ve hizmetleri kapsamaz. GSMH, üretimin yeryüzünde nerede gerçekleştiğine bakılmaksızın yerli şirketler tarafından üretilen tüm ürünleri ölçmektedir. Diğer bir ifade ile GSMH net dış faktör gelirlerini de kapsamakta ve bu gelirler çok sayıda ülkede istikrarlı bir seyir sergilememektedir (Erden-Özsoy \& Tosunoğu, 2017: 286).

\subsection{OECD Ülkelerinde ve Türkiye’de Kamu Kesimi Büyüklüğü}

Kamu kesiminin büyüklüğünün ne olması gerektiği ile ilgili tartışmalar halen devam etse de söz konusu büyüklüğün ekonomi içerisindeki payı genelde artış göstermektedir. Çok sayıda gelişmiş ülkede ise önemli bir paya sahip olduğunu söylemek mümkündür. Söz konusu ifade, Tablo 2'de verilen OECD ülkelerinde kamu kesimi büyüklükleri ile gözlenmektedir.

2007-2020 dönemine ait veriler incelendiğinde OECD üyesi ülkelerde kamu kesimi büyüklüğünün \%40 civarında olduğu görülmektedir. Avusturya, Belçika, Danimarka, Fransa ve İsveç gibi birçok gelişmiş ülkede kamu harcamalarının GSYH'ye oranı, diğer bir ifade ile kamu kesiminin büyüklüğü genel olarak \%50'ye yakın veya üzerinde bir seviyede seyretmektedir. Bu durum özellikle Kıta Avrupası'ndaki ülkelerdeki refah devleti anlayışı ile açıklanabilir. Ayrıca tabloda dikkat çeken bir diğer husus kamu kesimi büyüklüğü neredeyse ülkelerin tamamında 2009 yılına kadar sürekli artış göstermiş ve 2009 yılından sonra da azalma eğilimine girmesidir Türkiye özelinde incelendiğinde ise Türkiye'de kamu kesimi büyüklüğünün son dönemde yaklaşık \%35 seviyelerinde olduğu görülmektedir. Diğer ülkelere benzer şekilde Türkiye'de de 2008 yılındaki yükseliş de dikkat çekmektedir. Bu artışın sebebi ABD'de ortaya çıkan ve tüm dünyayı olduğu gibi Türkiye'yi de etkileyen Mortgage krizidir. Türkiye krizden etkilenmiş fakat bu etkilenme ciddi boyutlara ulaşmamıştır. Kriz sonrasında kamu kesimi büyüklüğünde ciddi dalgalanmalar yaşanmamış ve kamu kesimi büyüklüğü krizi takip eden yıllarda azalma trendine girmiştir. 
Tablo: 2

\section{OECD Ülkelerinde Kamu Kesiminin Büyüklüğü (Kamu Harcamaları / GSYH, \% $)^{4}$}

\begin{tabular}{|c|c|c|c|c|c|c|c|c|c|c|c|c|c|c|}
\hline ÜLKE & 2007 & 2008 & 2009 & 2010 & 2011 & 2012 & 2013 & 2014 & 2015 & 2016 & 2017 & 2018 & 2019 & 2020 \\
\hline Avustralya & 34,67 & 36,99 & 38,37 & 36,93 & 37,2 & 36,33 & 36,6 & 36,74 & 37,38 & 36,68 & 36,85 & 36,56 & 41,14 & \\
\hline Avusturya & 49,24 & 49,87 & 54,14 & 52,84 & 50,9 & 51,21 & 51,65 & 52,43 & 51,13 & 50,07 & 49,3 & 48,75 & 48,56 & 57,89 \\
\hline Belçika & 48,56 & 50,78 & 54,68 & 53,88 & 55,3 & 56,48 & 56,12 & 55,6 & 53,72 & 53,12 & 52,04 & 52,2 & 52,1 & 60,18 \\
\hline Kanada & 39,34 & 39,59 & 44,28 & 43,9 & 42,38 & 41,72 & 40,77 & 39,16 & 40,83 & 41,56 & 41,26 & 41,65 & 41,73 & 53,28 \\
\hline Kolombiya & 37,07 & 36,3 & 38,24 & 37,23 & 37,42 & 39,15 & 40,92 & 45,14 & 45,01 & 43,29 & 44,85 & $45,07 * *$ & 45,94 & \\
\hline Kosta Rika & $30,71 *$ & $34,97 *$ & $34,84 *$ & $38,72 *$ & $38,41^{*}$ & $30,91^{*}$ & $32,15^{*}$ & $31,98^{*}$ & $32,05^{*}$ & $32,53^{*}$ & $33,03^{*}$ & $42,07^{*}$ & 43,62 & \\
\hline Çek Cumhuriyeti & 40,44 & 40,87 & 44,36 & 43,63 & 43,19 & 44,68 & 42,65 & 42,62 & 41,93 & 39,75 & 38,98 & 40,6 & 41,36 & 47,5 \\
\hline Danimarka & 49,59 & 50,41 & 56,54 & 56,67 & 56,43 & 57,95 & 55,82 & 55,22 & 54,53 & 52,48 & 50,55 & 50,55 & 49,24 & 53,99 \\
\hline Estonya & 33,74 & 39,4 & 45,59 & 39,94 & 37,09 & 38,95 & 38,18 & 37,52 & 39,24 & 39,07 & 39,19 & 39,29 & 38,93 & 45,13 \\
\hline Finlandiya & 46,57 & 47,88 & 54,09 & 53,91 & 53,66 & 55,44 & 56,82 & 57,28 & 56,49 & 55,65 & 53,63 & 53,37 & 53,19 & 56,68 \\
\hline Fransa & 52,57 & 53,3 & 57,15 & 56,88 & 56,29 & 57,11 & 57,23 & 57,21 & 56,8 & 56,69 & 56,5 & 55,71 & 55,62 & 62,44 \\
\hline Almanya & 43,4 & 44,2 & 48,2 & 48,14 & 45,24 & 44,92 & 44,94 & 44,3 & 44,14 & 44,35 & 44,2 & 44,46 & 45,17 & 51,09 \\
\hline Yunanistan & 47,07 & 50,85 & 54,08 & 52,96 & 55,12 & 56,71 & 62,87 & 50,7 & 54,13 & 50,02 & 48,47 & 48,48 & 47,85 & 60,69 \\
\hline Macaristan & 49,94 & 48,8 & 50,68 & 48,91 & 49,12 & 49,25 & 50,16 & 50,14 & 50,42 & 46,85 & 46,5 & 45,89 & 45,71 & 51,62 \\
\hline İzlanda & 44,79 & 63,45 & 53,67 & 48,9 & 50,65 & 47,85 & 46,08 & 45,94 & 43,57 & 46,52 & 44,49 & 43,99 & 43,43 & 49,69 \\
\hline İlanda & 35,96 & 41,88 & 47,14 & 65,11 & 46,91 & 42,52 & 40,82 & 37,84 & 29,3 & 28,27 & 26,33 & 25,7 & 24,57 & 28,42 \\
\hline İsrail & 42,06 & 42,75 & 42,8 & 41,06 & 40,62 & 41,18 & 41,16 & 39,61 & 38,52 & 38,71 & 39,55 & 40,4 & 39,93 & \\
\hline İtalya & 46,78 & 47,83 & 51,11 & 49,93 & 49,17 & 50,59 & 50,95 & 50,86 & 50,32 & 49,08 & 48,76 & 48,38 & 48,63 & 57,29 \\
\hline Japonya & 35 & 36,07 & 40,69 & 39,74 & 40,64 & 40,61 & 40,76 & 40,2 & 39,33 & 39,29 & 38,64 & 38,83 & & \\
\hline Kore & 28,04 & 29,81 & 32,28 & 29,6 & 30,38 & 30,8 & 30,13 & 30,42 & 30,4 & 30,3 & 30,27 & 31,15 & 33,92 & \\
\hline Litvanya & 35,29 & 38,13 & 44,95 & 42,38 & 42,51 & 36,13 & 35,49 & 34,7 & 35,09 & 34,19 & 33,15 & 33,84 & 34,63 & 43,47 \\
\hline Letonya & 34,59 & 38,39 & 45,23 & 45,99 & 40,92 & 38,56 & 38,23 & 38,94 & 38,65 & 37,38 & 38,72 & 39,36 & 38,41 & 43,6 \\
\hline Lüksemburg & 37,86 & 39,8 & 45,09 & 44,28 & 42,62 & 44,1 & 43,54 & 42,22 & 41,98 & 41,02 & 42,26 & 42,34 & 42,32 & 47,79 \\
\hline Mesika & 21,59 & 25,03 & 25,47 & 25,44 & 28,79 & 28,53 & 28,44 & 28,05 & 28,2 & 26,67 & 26,1 & 27,46 & 26,74 & 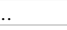 \\
\hline Hollanda & 42,46 & 43,22 & 47,67 & 47,94 & 46,84 & 46,86 & 46,6 & 45,86 & 44,69 & 43,6 & 42,4 & $42,25 * *$ & $41,97 * *$ & 48,14 \\
\hline Yeni Zelanda & 38,28 & 41,16 & 41,67 & 47,36 & 43,54 & 42,09 & 40,19 & 39,77 & 38,83 & 38,89 & 37,77 & 38,45 & 40,53 & \\
\hline Norveç & 41,74 & 40,58 & 46,5 & 45,39 & 44,18 & 43,31 & 44,41 & 46,25 & 49,28 & 51,53 & 50,48 & 48,82 & 51,47 & 58,36 \\
\hline Polonya & 42,9 & 44,17 & 45,01 & 45,85 & 44,09 & 43,15 & 42,98 & 42,64 & 41,68 & 41,11 & 41,27 & 41,54 & 41,87 & 48,8 \\
\hline Portekiz & 44,51 & 45,34 & 50,22 & 51,9 & 50,02 & 48,89 & 49,92 & 51,74 & 48,25 & 44,84 & 45,37 & 43,24 & 42,53 & 48,45 \\
\hline Slovak Cumhuriyeti & 36,38 & 36,99 & 44,41 & 42,5 & 41,63 & 41,15 & 42,5 & 43,3 & 45,77 & 42,66 & 41,33 & 41,66 & 42,68 & 47,99 \\
\hline Slovenya & 43,41 & 45,05 & 49,36 & 50,18 & 50,86 & 49,35 & 60,27 & 50,84 & 48,71 & 46,16 & 44,07 & 43,53 & 43,3 & 51,98 \\
\hline İspanya & 39,26 & 41,44 & 46,23 & 46,03 & 46,15 & 48,66 & 45,83 & 45,11 & 43,89 & 42,44 & 41,2 & 41,66 & 42,05 & 52,28 \\
\hline İsveç & 49,29 & 50,03 & 52,26 & 50,39 & 49,67 & 50,88 & 51,59 & 50,69 & 49,34 & 49,73 & 49,23 & 49,84 & 49,33 & 52,92 \\
\hline İsviçre & 30,09 & 30,64 & 32,46 & 32,12 & 32,09 & 32,42 & 33,32 & 32,91 & 33,23 & 33,3 & 33,26 & 32,55 & 32,72 & \\
\hline Türkiye & .. & & 37,72 & 35,31 & 33,32 & 33,21 & 32,59 & 31,94 & 31,74 & 33,85 & 33,96 & 34,69 & 35,45 & \\
\hline Birleşik Krallık & 40,99 & 44,37 & 47,2 & 47,27 & 45,77 & 45,62 & 43,92 & 43,09 & 42,28 & 41,54 & 41,26 & 41,06 & 41,1 & 51,56 \\
\hline $\mathrm{ABD}$ & 37,43 & 39,82 & 43,26 & 43,17 & 42,05 & 40,23 & 39,01 & 38,35 & 37,89 & 38,21 & 37,99 & 37,81 & 38,14 & \\
\hline OECD Ortalama & 40,6 & 42,72 & 46,15 & 45,95 & 44,84 & 44,67 & 44,88 & 44,1 & 43,57 & 42,71 & 42,18 & 42,18 & 42,45 & \\
\hline
\end{tabular}

\section{Ampirik Literatür}

Ulusal ve uluslararası literatür incelendiğinde vergi esnekliği ile ilgili farklı ülkeleri konu edinen çok sayıda çalışma mevcuttur. Ancak vergi esnekliği ile kamu kesimi büyüklüğü arasında ilişki kuran çalışma sayısı oldukça sınırlıdır. Bu konu hakkında literatürde ulusal ve uluslararası ampirik çalışmalar Tablo 3’te verilmiştir.

4 OECD (2021)'den temin edilen veri setinde Şili'ye ait veriler bulunmamaktadır. 
Tablo: 3

\section{Vergi Esnekliği ve Kamu Kesimi Büyüklüğü İlişkisine İlişkin Ampirik Çalışmalar}

\begin{tabular}{|c|c|c|c|c|}
\hline $\begin{array}{c}\text { Yazar/ } \\
\text { Çalışmanın } \\
\text { Yılı } \\
\end{array}$ & $\begin{array}{c}\text { Analizin } \\
\text { Yapıldığı } \\
\text { Yer } \\
\end{array}$ & $\begin{array}{l}\text { Analizin } \\
\text { Yapıldığı } \\
\text { Yıllar } \\
\end{array}$ & $\begin{array}{c}\text { Kullanılan } \\
\text { Ekonometrik } \\
\text { Yöntem } \\
\end{array}$ & Bulgular \\
\hline $\begin{array}{l}\text { Craig \& } \\
\text { Heins } \\
(1980)\end{array}$ & ABD Eyaletleri & $1970-1975$ & $\begin{array}{l}\text { Regresyon } \\
\text { Analizi } \\
\text { (En Küçük } \\
\text { Kareler } \\
\text { Yöntemi) }\end{array}$ & $\begin{array}{l}\text { Çalışmada vergi esnekliğinin hükümet harcamaları üzerindeki etkisi analiz } \\
\text { edilmiştir. Bağımlı değişkenler olarak kişi başı hükümet harcaması ve kişi başı } \\
\text { hükümet harcamalarının yüzdesi; bağımsız değişkenler olarak ise vergi } \\
\text { esnekliği, kişi başı gelir, kişi başı federal yardım, nüfus yoğunluğu, eyalet ve } \\
\text { yerel gelir, kentsel nüfus ve } 18 \text { yaş üstü nüfus. Analizlerin bulgularına göre } \\
\text { hükümetler tarafından yapılan harcama düzeylerinin vergi esnekliği ile pozitif } \\
\text { ilişkisi vardır. }\end{array}$ \\
\hline $\begin{array}{l}\text { Dilorenzo } \\
(1982)\end{array}$ & $\begin{array}{l}250.000 \text { veya daha } \\
\text { fazlası nüfusa sahip } \\
66 \text { eyalet bölgesi }\end{array}$ & $1867-1977$ & & $\begin{array}{l}\text { Çalışmada bağımlı değişken kişi başı harcamadaki değişim; bağımsız } \\
\text { değişkenler ise nüfustaki değişim, nüfus yoğunluğundaki değişim, kişi başı } \\
\text { gelirdeki değişim, vergi esnekliği, kişi başı yerel gelirdeki değişim, hükümetler } \\
\text { arası gelirdeki değişimdir. Çalışmadan elde edilen bulguya göre vergi esnekliği } \\
\text { ile yerel kamu harcaması arasındaki anlamlı ve negatif bir ilişki vardır. }\end{array}$ \\
\hline $\begin{array}{c}\text { Misiolek } \\
\text { \& Elder } \\
(1988)\end{array}$ & ABD Eyaletleri & $1967-1984$ & $\begin{array}{c}\text { Regresyon } \\
\text { Analizi }\end{array}$ & $\begin{array}{l}\text { Çalışmada iki bağımlı değişken kullanılmıştır. Bunlar kişi başı reel vergi geliri } \\
\text { ve kişi başı gerçek yerel-eyalet harcamașdır. Bağımsız değişkenler ise kişi başı } \\
\text { kişisel gelir, nüfus, eyalet yerel yönetim çalışanlarının aylık ortalama maaşı, } \\
\text { eyalet-yerel vergi gelirlerinin zaman içerisindeki değişimi, gerçek kişisel gelirin } \\
\text { zaman içerisindeki değişimi. Çalışmanın bulgularına göre vergi esnekliğinin } \\
\text { vergi gelirleri üzerindeki etkisi anlamlı ve pozitif iken, kamu harcamaları } \\
\text { üzerindeki etkisi yoktur. }\end{array}$ \\
\hline $\begin{array}{c}\text { Dollery \& } \\
\text { Worthingon } \\
\text { (1995) }\end{array}$ & 7 Avustralya Eyaleti & 1982-1992 & $\begin{array}{l}\text { Birleştirilmiş } \\
\text { Zaman } \\
\text { Serileri }\end{array}$ & $\begin{array}{l}\text { Bağımlı değişken kişi başı kamu harcaması; bağımsız değişkenler kişi başı gelir, } \\
65 \text { yaş üstü nüfus oranı, } 19 \text { yaş altı nüfus oranı, nüfus yoğuluğu, vergi esnekliği, } \\
\text { dolaylı ve dolaysız vergi oranı. Elde edilen sonuçlara göre vergi esnekliğinin } \\
\text { kamu harcamaları üzerinde etkisi yoktur. }\end{array}$ \\
\hline $\begin{array}{l}\text { Adejare } \\
\text { \& Akande } \\
(2017)\end{array}$ & Oyo Eyaleti & $1990-2015$ & $\begin{array}{l}\text { Çoklu } \\
\text { Regresyon } \\
\text { Modeli }\end{array}$ & $\begin{array}{l}\text { Çalışmada Oyo Eyaletinde kişisel gelir vergisinin devlet harcamaları üzerindeki } \\
\text { etkisi analiz edilmiştir. Bağımlı değişken Oyo eyaleti kamu harcamaları; } \\
\text { bağımsız değişkenler kişisel gelir vergisi (PAYE), sermaye kazanç vergisi, yol } \\
\text { vergisi ve diğer vergilerdir. (Damga vergisi, bahis ve kumar vergileri, ticari } \\
\text { tesisler ve tescil vergileri vb). Elde edilen bulgulara göre Kişisel gelir vergisinin } \\
\text { kamu harcamaları üzerinde olumlu bir etkisi vardır. Oyo eyaletinde kamu } \\
\text { harcamaları üzerinde negatif önemsiz etkilere sahip olan sermaye kazanç vergisi } \\
\text { ve yol vergisi haricinde, diğer tüm değişkenler Oyo eyaletindeki kamu } \\
\text { harcamaları üzerinde pozitif anlamlı etkiye sahiptir. }\end{array}$ \\
\hline $\begin{array}{l}\text { Patnaik } \\
\text { \& Yaji } \\
(2018)\end{array}$ & $\begin{array}{l}\text { Hindistan'ın } 5 \text { büyük } \\
\text { eyaleti (Andhra } \\
\text { Pradesh, } \\
\text { Maharashtra, Uttar } \\
\text { Pradesh, Bihar ve } \\
\text { Punjab.) }\end{array}$ & $2001-2010$ & $\begin{array}{c}\text { Regresyon } \\
\text { Analizi }\end{array}$ & $\begin{array}{l}\text { Çalışmada bağımlı değişken olarak eyalet düzeyinde devlet harcamaları; } \\
\text { bağımsız değişken olarak ise GSYH, merkezi yardım ve vergi esnekliği } \\
\text { kullanılmıştır. } \\
\text { Analiz sonucuna göre Bihar hariç diğer eyaletlerde devlet harcamaları ile vergi } \\
\text { esnekliği arasında pozitif bir ilişki mevcuttur. Dolayısıla, vergi esnekliğine } \\
\text { sahip bir devlet, yasal vergi oranlarında bir değişiklik olmaksızın (gelirini } \\
\text { artırmak için) bile harcamalarını artırabilir. }\end{array}$ \\
\hline $\begin{array}{l}\text { Kutbay } \\
\text { \& Aksoy } \\
(2020)\end{array}$ & $\begin{array}{l}7 \text { OECD ülkesi } \\
\text { (Kanada, İzlanda, } \\
\text { Letonya, Litvanya, } \\
\text { Lüksemburg, } \\
\text { Hollanda ve İsviçre) }\end{array}$ & $1997-2016$ & $\begin{array}{l}\text { Panel } \\
\text { Veri } \\
\text { Analizi }\end{array}$ & $\begin{array}{l}\text { Çalışmada bağımlı değişken olarak kamu harcamaları, bağımsız değişkenler } \\
\text { olarak ise vergi esnekliği, tüketici fiyat endeksi ve nüfus artış, oranı kullanılmıştır. } \\
\text { Analiz sonucuna göre vergi esnekliği ve nüfus artışı kamu harcamalarını } \\
\text { artırmakta; tüketici fiyat endeksi ise kamu harcamalarını azaltmaktadır. }\end{array}$ \\
\hline $\begin{array}{l}\text { Y1lanci vd. } \\
\text { (2020) }\end{array}$ & Türkiye & $\begin{array}{l}\text { Ocak } 2006 \\
\text { / Kasim } \\
2019\end{array}$ & $\begin{array}{l}\text { Asimetrik } \\
\text { Nedensellik } \\
\text { Testi }\end{array}$ & $\begin{array}{l}\text { Çalışmanın amacı kamu harcamaları ile vergiler arasında nedensellik ilişkisinin } \\
\text { tespitidir. } \\
\text { Çalışma bulgularına göre uzun dönemde vergi gelirlerinden kamu harcamalarına } \\
\text { doğru tek yönlü bir nedensellik ilişkinin varlığı saptanırken, vergi gelirlerinin } \\
\text { pozitif şoklarından kamu harcamalarının pozitif şoklarına doğru, kısa, orta ve } \\
\text { uzun vadede tek yönlü asimetrik bir nedensellik ilişkinin varlığı saptanmışır. } \\
\text { Dolayısıyla uzun dönemde Türkiye'de vergi-harcama hipotezinin geçerli olduğu; } \\
\text { kısa, orta ve uzun vadelerde ise asimetrik vergi-harcama hipotezinin geçerli } \\
\text { olduğu bulgusuna ulaşılmıştır. }\end{array}$ \\
\hline
\end{tabular}

\section{Veri Seti ve Model}

Bu çalışma ile Türkiye'de kamu kesimi büyüklüğü ile vergi esnekliği arasındaki ilişki tespit edilmeye çalışılmıştır. Vergi esnekliği test edilirken toplam vergi geliri esnekliği dikkate alınmış ve genel bütçe vergi gelirlerine ilişkin esneklik katsayıları tarafımızca hesaplanmıştır. Hesaplama yapılırken toplam vergi gelirleri tahsilat tutarları Gelir İdaresi 
Başkanlığı'ndan, GSYH verileri ise 1990-2017 dönemi Strateji ve Bütçe Başkanlığı, 20182019 yılları ise TÜİK'ten temin edilmiştir. Modelde kullanılan diğer değişken olan kamu kesimi büyüklüğü ise 1990-2003 dönemi için Strateji ve Bütçe Başkanlığı'nın; 2004-2019 dönemi ise Hazine ve Maliye Bakanlığı'nın resmi internet sayfasından temin edilmiştir. Ayrıca modelde kullanılan nüfus değişimi değişkeninin verileri Dünya Bankası'ndan temin edilmiştir. Verilerin devamlılığı açısından modelde kullanılacak dönem 1990-2019 olarak belirlenmiştir.

Seriler arasındaki nedensellik ilişkisinin test edilebilmesi için öncelikle serilerin durağanlık sınamasının yapılması gerekmektedir. Serilerin durağan olmaması, sahte regresyon problemi ile karşı karşıya olmamıza neden olacağından, değişkenin farkının alınması gerekmektedir. Orijinal seride fark almayı her gözlem arasındaki değişme olarak tanımlamak mümkündür (Sevüktekin \& Nargeleçekenler, 2010: 237). Durağan hale getirilebilmesi için $\mathrm{x}$ defa farkının alınması gereken bir değişken; I(x) olarak ifade edilmektedir. Durağanlığı sınamak için kullanılan bir yöntem birim kök sınamasıdır. Bu durumun tespiti için modeldeki değişkenlere ait serilere, ekonometrik modellerde durağanlığın tespitinde çoğunlukla kullanılan ADF (Augumented Dickey Fuller) ve PhillipsPerron (PP) Birim Kök Testleri uygulanmıştır (Gujarati, 1999: 718-719).

Durağan olmayan zaman serilerinin düzey değerleriyle ele alınıp alınamayacağını anlamak için eşbütünleşme testinin yapılması gerekir. Eşbütünleşme ekonomik değişkenler arasındaki uzun dönemli ilişkinin istatistiksel olarak sunulmasıdır (Sevüktekin \& Nargeleçekenler, 2010: 481). Serilerin düzey değerleriyle yapılan birim kök sınamasında durağan olmadıkları anlaşıldığından birinci derece farkları alınarak durağan hale getirilmiş ve koentegrasyon araştırılmıştır. Aynı dereceden farkı alındığında durağan hale getirilen seriler arasında koentegrasyon (eşbütünleşme) olması durumunda Engle ve Granger tarafından 1987 yılında geliştirilen Hata Düzeltme Modeli kullanılmaktadır.

Analizde kullanılan değişkenler;

eTV: Toplam vergi gelirleri için esneklik katsayıları,

rGSYH: Gayrisafi yurt içi hasıla (Zincirlenmiş hacim endeksine göre olan değerler analize dahil edilmiştir),

ND: Nüfus değişimi,

KKB: Kamu kesimi büyüklüğü,

$\Delta$ : Her bir değişkenin birinci dereceden farkı şeklindedir.

\section{Analiz Sonuçları}

Kamu kesimi ile vergi esnekliği arasındaki ilişkinin test edilmesi için yapılan analizler Eviews 10.0 ekonometri paket programı yardımıyla gerçekleştirilmiştir. Öncelik olarak serilerin durağanlığını incelemek için birim kök testleri yapılmaktadır. Durağan olmayan serilerle çalışılması halinde, sahte regresyon problemi ile karşılaşılabileceği ve bu 
durumda regresyon analizi ile elde edilen sonuçların geçersiz sayılacağı ifade edilmektedir. Durağan olmayan seriler ile yapılan regresyon analizlerinin, sadece bu seriler arasındaki eşbütünleşme (koentegrasyon) ilişkisi varsa gerçek ilişkiyi yansıtacağı kabul edilmektedir (Gujarati, 1999: 726).

\subsection{Birim Kök Testleri}

Durağan olmayan seriler birçok hipotez testini geçersiz kıldığı için bu sorunu ortadan kaldırmak için Augumened Dickey- Fuller (ADF) testi ve Philips-Perron Testi kullanılmıştır. Buna göre; Ho: seri durağan değildir (birim köke sahiptir) iken alternatif hipotez olarak Ha: seri durağandır (birim köke sahip değildir) şeklindedir.

Tablo: 4

ADF Testi ve Philips-Perron Testi Sonuçları

\begin{tabular}{|c|c|c|c|c|}
\hline \multirow{2}{*}{ DEĞİŞKENLER } & \multicolumn{2}{|c|}{ ADF-t istatistiği Düzey Değerleri } & \multicolumn{2}{|c|}{ ADF-t istatistiği Birinci farkları } \\
\hline & Sabit & Sabit ve Trendli & Sabit & Sabit ve Trendli \\
\hline KKB & $-2.480(0.13)$ & $-2.458(0.34)$ & $-4.889\left(0.00^{* *}\right)$ & $-4.919\left(0.00^{* *}\right)$ \\
\hline logrGSYH & $-0.001(0.95)$ & $-2.255(0.44)$ & $-5.722(0.00 * *)$ & $-5.709(0.00 * *)$ \\
\hline eTV & $-2.433(0.14)$ & $-6.458\left(0.00^{* *}\right)$ & $-5.522(0.00 * *)$ & $-6.221\left(0.00^{* *}\right)$ \\
\hline ND & $-2.105(0.24)$ & $-4.165(0.01 *)$ & $-3.675(0.01 *)$ & $-4.997(0.00 * *)$ \\
\hline DEĞİŞKENLER & \multicolumn{2}{|c|}{ Philips-Perron istatistiği Düzey Değerleri } & \multicolumn{2}{|c|}{ Philips-Perron istatistiği Birinci farkları } \\
\hline & Sabit & Sabit ve Trendli & Sabit & Sabit ve Trendli \\
\hline KKB & $-2.328(0.17)$ & $-1.990(0.58)$ & $-4.889\left(0.00^{* *}\right)$ & $-4.921(0.00 * *)$ \\
\hline logrGSYH & $0.144(0.96)$ & $-2.255(0.44)$ & $-6.016\left(0.00^{* *}\right)$ & $-7.419\left(0.00^{* *}\right)$ \\
\hline eTV & $-5.196(0.00 * *)$ & $-5.801(0.00 * *)$ & $-13.751\left(0.00^{* *}\right)$ & $-15.888\left(0.00^{* * *}\right)$ \\
\hline ND & $-1.858(0.34)$ & $-1.866(0.64)$ & $-6.911(0.01 *)$ & $-6.594(0.01 *)$ \\
\hline
\end{tabular}

* işareti \%5 düzeyinde anlamllliğl ifade etmektedir.

** işareti \%1 düzeyinde anlamlllığ ifade etmektedir.

Sadece reel olarak hesapladığımı GSYH değer içermekte, diğer değiş̧enler \% olarak ifade edildiğinden, sadece rGSYH değişkeninin önce mutlak değeri ardından logaritması alınmıştır.

ADF ve Philip-Perron testi sonucunda, serilerin birinci derece farklarının alınması durumunda tümünün durağan hale geldiği gözlenmiştir. Serilerin bir kısmının düzeyde durağan bir kısmının da birinci derece farkları ile durağan olması, aynı seviyede durağan olmadıklarını göstermektedir. Oysaki analize devam etmek için tümünün aynı seviyede durağanlığının sağlanması önemlidir. Söz konusu durağanlık ise birinci dereceden farklarının alınmasıyla sağlanmıştır.

Serilerin geleneksel birim kök testlerine göre (ADF ve PP) göre I(1) olmasından dolayı seriler arasındaki eşbütünleşme ilişkisinin araştırılabileceğine karar verilmiştir. Durağan olmayan fakat aynı düzeyde farkları alınarak durağanlığı yakalayan serilerde Granger Nedensellik Testleri ile bulunan bulgular sahte olabilir. Bu nedenle farklı koentegrasyon teknikleri yardımıyla, seriler arasındaki uzun dönemli ilişkinin varlığı araştırılır.

\subsection{Johansen Eşbütünleşme Testi}

ADF ve PP birim kök test sonuçlarına göre, seriler düzeyde durağan olmayıp birinci derece farkları alınınca ancak durağan olmuştur. Dolayısıyla aynı dereceden durağan 
olmaları eşbütünleşme testi için gerekli ilk aşamanın sağlandığını göstermektedir. Bu durumda seriler arasındaki uzun dönemli ilişki Johansen eşbütünleşme yöntemiyle test edilebilir. Johansen eşbütünleşme testi için uygun gecikmenin belirlenmesin ve seriler arasında uzun dönemli ilişkinin olup olmadığının test edilmesi gereklidir. VAR modeli ile uygun olan gecikme uzunluğu bulunacak ve bazı kriterler dikkate alınacaktır. Bunlar AIC, FPE, SC, LR, HQ kriterleri şeklindedir.

Tablo: 5

VAR Modeline Uygun Gecikme Uzunluğunun Belirlenmesi

\begin{tabular}{|c|c|c|c|c|c|}
\hline Gecikme Sayis1 & LR & FPE & AIC & SC & HQ \\
\hline 1 & 115.102 & 0.003 & 5.776 & $\mathbf{6 . 7 7 4} *$ & 6.054 \\
\hline 2 & $\mathbf{2 9 . 9 9 8} *$ & $\mathbf{0 . 0 0 2}^{*}$ & $\mathbf{5 . 2 4 2}^{*}$ & 6.984 & $\mathbf{5 . 7 4 4} *$ \\
\hline
\end{tabular}

LR: Sequential modified LR test statistics, FPE: Final prediction error, AIC: Akaike information criterion, $S C$ : Schwarz information criterion, HQ: Hannan-Quinn information criterion.

VAR modeline uygun olan gecikme uzunluğu sayısı, kriterlerden çoğunluğunun yani 3 tanesinin sonucuna göre 2 olarak belirlenmektedir. Uygun olan gecikme uzunluğuna göre yapılan Johansen Koentegrasyon Testi sonucunda, koentergrasyonun olmadığ edilmiştir.

Tablo: 6

Johansen Eşbütünleşim Testi Sonuçları

\begin{tabular}{|c|c|c|c|c|c|}
\hline Sıfir Hipotezi & Maksimum öz değer istatistiği & \%95 kritik değer & İz istatistiği & \%95 kritik değer & Öz değer \\
\hline $\mathrm{r}=0$ & $\mathbf{4 4 . 2 9 3}^{2}$ & $\begin{array}{c}24.159 \\
(0.00)\end{array}$ & $\mathbf{8 1 . 6 8 2}^{*}$ & $\begin{array}{c}40.174 \\
(0.00)\end{array}$ & 0.817 \\
\hline $\mathrm{r} \leq 1$ & $\mathbf{3 6 . 1 8 5}^{*}$ & $\begin{array}{c}25.823 \\
(0.00)\end{array}$ & $\mathbf{5 3 . 7 1 7 *}$ & $\begin{array}{c}42.915 \\
(0.03)\end{array}$ & 0.805 \\
\hline $\mathrm{r} \leq 2$ & 12.724 & $\begin{array}{c}19.387 \\
(0.35)\end{array}$ & 17.531 & $\begin{array}{c}25.872 \\
(0.37)\end{array}$ & 0.387 \\
\hline
\end{tabular}

Not: $r$, eşbütünleşme sayısını, *, \%5 düzeyindeki anlamlılı̆̆ ifade etmektedir.

Eşbütünleşme testi, eşbütünleşik vektörün liner olup, sabit ve trend içerdiği modele uygun olarak gerçekleştirilmiştir. Hesaplanan test istatistikleri belli bir anlamlılık düzeyindeki $\% 5$ kritik değerden büyükse HO hipotezi reddedilir. (H0: eşbütünleşme yoktur). Maksimum özdeğer ve iz istatistiklerine göre, eşbütünleşme vardır. Bu sonuçlara göre, analiz dönemi içerisinde Türkiye'de modelde yer alan değişkenler arasında uzun dönemli bir denge ilişkisinin geçerli olduğundan söz etmek mümkündür.

\subsection{Değişkenler Arasındaki Nedensellik İlişkisinin Vektör Hata Düzeltme Modeli (VECM) ile Belirlenmesi}

Eşbütleşmenin varlığı durumunda nedensellik ilişkilerinin hata düzeltme modeli (Vector Error Correction Model, VECM) ile analiz edilmesi gerekmektedir. Değişkenler arasında uzun dönemli bir ilişki olması halinde Engle ve Granger (1987) çalışmalarında hata düzeltme mekanizmasının kullanılabileceğini göstermişlerdir. Böylece uzun dönem dengesinde oluşacak bir sapmanın düzeltilebileceği ortaya atılmıştır. Burada kullanılacak olan regresyonda sapmaların düzeltilmesi için hata düzeltme terimi (ECT) kullanılmaktadır. Dolayısıyla çalışmada kullanılan zaman serileri arasında incelenecek Granger nedensellik 
testi vektör hata düzeltme modeli (VECM) temelli olacaktır. Burada kullanılacak olan her bir bağımlı değişken için açıklayıcı değişkenlerin katsayılarına uygulanan Wald testinden elde edilen $\mathrm{F}$ istatistik değerleri ile hata düzeltme terimlerinin katsayılarının $\mathrm{t}$ istatistik değerleri Tablo 7'de gösterilmiştir. Sınamaya ilişkin hata düzeltme denklemleri aşağıdaki gibidir:

$$
\begin{aligned}
& \Delta \log G S Y H_{t}=\propto_{0}+\propto_{1} \Delta \log G S Y H_{t-1}+\propto_{2} \Delta e T V G_{t}+\propto_{3} \Delta e T V G_{t-1}+\propto_{4} \Delta n u f u s D_{t}+ \\
& \propto_{5} \Delta \text { nufus } D_{t-1}+\propto_{6} \Delta K K B_{t}+\propto_{7} \Delta K K B_{t-1+} \propto_{8} e 1_{t-1}+\varepsilon_{t 1} \\
& \Delta e T V G_{t}=\beta_{0}+\beta_{1} \Delta e T V G_{t-1}+\beta_{2} \Delta \log G S Y H_{t}+\beta_{3} \Delta \log G S Y H_{t-1}+\beta_{4} \Delta n u f u s D_{t}+ \\
& \beta_{5} \Delta \text { nufus } D_{t-1}+\beta_{6} \Delta K K B_{t}+\beta_{7} \Delta K K B_{t-1+} \beta_{8} e 1_{t-1}+\varepsilon_{t 2} \\
& \Delta \text { nufus } D_{t}=\delta_{0}+\delta_{1} \Delta \text { nufus } D_{t-1}+\delta_{2} \Delta \log G S Y H_{t}+\delta_{3} \Delta \log G S Y H_{t-1}+\delta_{4} \Delta e T V G_{t}+ \\
& \delta_{5} \Delta e T V G_{t-1}+\delta_{6} \Delta K K B_{t}+\delta_{7} \Delta K K B_{t-1}+\delta_{8} e 1_{t-1}+\varepsilon_{t 3} \\
& \Delta K K B_{t}=£_{0}+£_{1} \Delta K K B_{t-1}+£_{2} \Delta \log G S Y H_{t}+£_{3} \Delta \log G S Y H_{t-1}+£_{4} \Delta e T V G_{t}+£_{5} \Delta e T V G_{t-1}+ \\
& £_{6} \Delta \text { nufus } D_{t}+£_{7} \Delta \text { nufus } D_{t-1}+£_{8} e 1_{t-1}+\varepsilon_{t 4}
\end{aligned}
$$

\begin{tabular}{|c|c|c|c|c|c|c|}
\hline \multirow{3}{*}{ Bağımlı Değişken } & \multirow{2}{*}{\multicolumn{4}{|c|}{$\begin{array}{l}\text { Kısa Dönem Nedensellik } \\
\text { Bağımsız Değiskkenler }\end{array}$}} & \multicolumn{2}{|c|}{ Uzun dönem Nedensellik } \\
\hline & & & & & & \\
\hline & KKB & logrGSYH & ND & eTV & ECT & $\mathrm{t}$ ist. \\
\hline KKB & - & $\begin{array}{c}0.055 \\
(0.003)^{*}\end{array}$ & $\begin{array}{c}8.877 \\
(\mathbf{0 . 0 0 1})^{*}\end{array}$ & $\begin{array}{c}0.628 \\
(0.543) \\
\end{array}$ & $\begin{array}{c}-1.30 \\
{[0.00]^{*}}\end{array}$ & -6.78 \\
\hline logrGSYH & $\begin{array}{c}0.439 \\
(0.649) \\
\end{array}$ & - & $\begin{array}{c}4.617 \\
(0.020)^{*}\end{array}$ & $\begin{array}{c}0.511 \\
(0.606) \\
\end{array}$ & $\begin{array}{c}0.006 \\
{[0.01]}\end{array}$ & 6.46 \\
\hline ND & $\begin{array}{c}0.052 \\
(0.949) \\
\end{array}$ & $\begin{array}{c}0.922 \\
(0.912) \\
\end{array}$ & - & $\begin{array}{c}0.139 \\
(0.870)\end{array}$ & $\begin{array}{l}-\mathbf{- 0 . 3 0 0} \\
{[0.00]^{*}}\end{array}$ & -7.32 \\
\hline eTV & $\begin{array}{c}1.367 \\
(0.276) \\
\end{array}$ & $\begin{array}{c}2.434 \\
(0.110)\end{array}$ & $\begin{array}{c}1.697 \\
(0.205)\end{array}$ & - & $\begin{array}{l}-3.164 \\
{[0.00]^{*}}\end{array}$ & -15.47 \\
\hline
\end{tabular}

Tablo: 7

Hata Düzeltme Modeline Dayalı Nedensellik Testi Sonuçlar

Not: $t$ istatistiği kritik değerden büyükse anlamlıdır, diğer ifade ile nedensellik kaynağıdır. *\%5 önem düzeyinde anlamlılı̆̆ı gösterir. () kusa dönem analizde prob. değerleridir, []uzun dönem analizde prob. değerleridir.

Tabloda gösterilen değişkenlere ait ECT'nin (hata terimi) t istatistiği değerlerinin kritik değerlerden büyük olması halinde, bağımlı değişkenin uzun dönemde diğer değişkenlerle arasında nedensellik ilişkisi olduğu sonucuna ulaşılmıştır. Burada önemli olan ECT için prob. yani olasılık değerinin 0.05 'den küçük olması ve katsayı değerinin mutlaka (-) işaretli olması gereklidir. Buradan hareketle tabloda yer alan sonuçlara göre uzun dönemde KKB, eTV, ND bağımlı değişken oldukları zaman diğerlerine doğru nedensellik ilişkisinin mevcut olduğu ancak logrGSYH'den diğer değişkenlere doğru uzun dönemli nedensellik ilişkisinin olmadığı söylenebilmektedir. Kısa dönemde ise ND’den KKB ve logrGSYH'ye doğru bir nedensellik tespit edilmiştir. KKB ile eTV arasında kısa dönemli nedensellik söz konusu değildir.

Tablo 7'deki kısa dönem nedensellik testi sonuçlarına göre, nüfus değişiminden kamu kesimi büyüklüğüne ve GSYH'den da yine kamu kesimi büyüklüğüne doğru doğru tek yönlü pozitif nedensellik ilişkisinin olduğu görülmektedir. Nüfus değişimi arttıkça kamu kesimi büyümekte yani kamu harcamalarının hasıla içindeki payı artmaktadır. Aynı zaman nüfus ülkedeki GSYH'nin artmasına da etki etmektedir. 
Şekil: 1

Kısa Dönem Nedensellik Analizi Sonucu

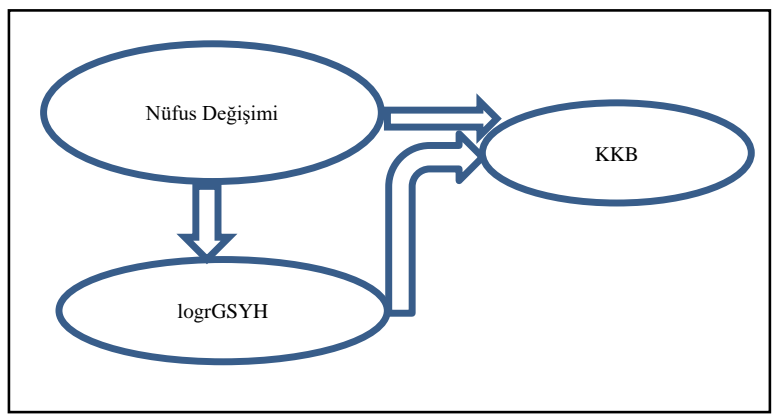

Kısa dönem nedensellik testi sonuçlarında, çalışmanın konusunu oluşturan kamu kesimi büyüklügü ile vergi gelirleri esnekliği ilişkisi gözlenmemektedir. Elde edilen bulgulara göre kamu kesimi büyüklüğünden vergi gelirleri esnekliğine doğru bir nedensellik mevcut değildir. Bu sonuçtan yola çıkarak Türkiye'de kısa dönemde kamu kesiminin genişlemesi ile vergi gelirlerinin esnekliği arasında bir ilişki yoktur. Benzer sonuç literatürde yer alan Dollery ve Worthing (1995) ile Misiolek ve Elder (1988) tarafindan yapılan farklı ülke örneklerinin ve farklı dönemlerin ele alındığı çalışmalarda da söz konusudur. Bunun yanında literatürde oldukça az çalışma olmakla birlikte Debasis ve Venkat (2018: 70) vergi esnekliği ile hükümet harcamaları arasında pozitif ve anlamlı bir ilişki tespit etmiştir. Sonuçların birbirinden farklı olmasının nedeni, yapılan çalışmalarda farklı ülke örnekleri ve farklı dönemlerin alınmasıdır.

Yapılan analizlerden elde edilen bulgularına göre ekonomik büyüme ile kamu kesimi büyüklüğü arasında da kısa dönemde tek yönlü pozitif nedensellik tespit edilmiş olup bu sonuç yapılan diğer çalışmalar ile desteklenmektedir. Türkiye'de kamu büyüklüğünün iktisadi büyüme üzerindeki etkilerini test etmeye yönelik yapılan ampirik çalışmalar arasında Yamak ve Küçükkale (1997) ile Terzi (1998); ekonomik büyümenin Granger anlamında kamu harcamalarını pozitif yönde etkilediğini tespit etmişlerdir. Elde ettikleri sonuç, Türkiye'de kamu harcamaları payındaki artışın ekonomik gelişmeyle birlikte arttığı yönündedir. Aslında bu sonuç bir anlamda Wagner Yasasının geçerli olduğunu ortaya koymuştur.

\section{Sonuç}

Devletler artan kamu harcamalarının finansmanı için vergi gelirlerine ihtiyaç duyarlar. Vergilerin ise optimum bir şekilde tahsil edilmesi etkin bir vergi sistemi ile mümkündür. Vergilemede etkinliğin ölçülmesi yöntemi olan vergi esnekliği vergi sistemleri için arzu edilen bir durumdur. 
Vergi esnekliği vergi sistemi için ölçülebileceği gibi her bir vergi türü için de hesaplanabilmektedir. Genel bütçe vergi gelirleri, gelir vergisi, kurumlar vergisi ve katma değer vergisi 2000-2019 dönemi vergi esneklikleri dalgalı seyir izlemekte ayrıca katma değer vergisi hariç diğer vergilerde ve toplam vergi gelirlerinin esnekliğinde 2009 yılındaki yükseklik dikkat çekmektedir. Bunun nedeni olarak 2008 yılındaki Mortgage krizi gösterilebilir. Söz konusu vergiler arasında 2009 yılı için esneklik katsayısı en fazla olan vergi kurumlar vergisidir. Kurumlar vergisi esnekliğinin bu denli yüksek olmasının sebebi, küresel krizin etkisi ile GSYH'de düşüş yaşanması ve buna karşılık kurumlar vergisi tahsilat rakamlarında önemli ölçüde farklılık olmaması olarak açıklanabilir. Görüldüğü üzere ülkelerdeki ekonomik krizler, ekonomik göstergeleri etkilemektedir. Bu süreçte vergi gelirleri de elbette etkilenmekte, iradi vergi politikaları zaman zaman beklenen etkiyi gösterememekte ve otomatik stabilizatör olarak vergi sisteminin esnekliği önem arz etmektedir. Bir vergi sisteminin esnekliği, vergilerin otomatik stabilizatör olma özelliklerini etkilemektedir. Ülkedeki kamu kesiminin payı yani daha liberal bir devlet anlayışı ile daha müdahaleci devlet anlayışına sahip olan ülkelerde, vergi esnekliği ne düzeyde değişmekte ya da etkilenmektedir? sorusundan hareketle, sadece Türkiye özelinde, kamu kesimi büyüklüğü ile vergi gelirlerinin esnekliği arasındaki ilişki araştırılmıştır. Bu çalışma daha sonra gelişmiş ve gelişmekte olan ülke örnekleri ile desteklenerek, ülkedeki yönetim anlayış1 ile vergi esnekliği ilişkisinin belirlenmesi hedeflenmektedir.

Kamu kesimi büyüklüğü ile toplam vergi gelirleri esnekliği arasındaki ilişkinin Türkiye açısından ele alındığı çalışmada, 1990-2019 dönemi içinde geçerli olmak üzere değişkenler arasındaki kısa ve uzun dönemli nedensellik araştırılmıştır. Çalışmanın amacı kamu kesimi büyüklüğü arttıkça vergi gelirlerinin esnekliğinin bundan nasıl etkilendiğini yani aralarında bir nedensellik olup olmadığının ortaya konmasıdır. Yapılan analiz göstermektedir ki; kısa dönemde devletin ekonomideki rolünün artması ya da azalması, vergilerin otomatik stabilizatör olma özellikleri üzerinde bağlayıcı etkiye sahip değildir. Türkiye örneğinde çıkan bu sonuç, bazı uluslararası çalışmalarda da her ne kadar farklı ülke ve dönemler ele alınmış olsa da benzer niteliktedir. Uzun dönemli test sonuçlarında ise, Türkiye'de eTV'nin yani vergilerin gelir esnekliğinin bağımlı değişken olarak ele alındığ durumda, söz konusu değişkenden diğer değişkenlere doğru uzun dönemli nedensellik ilişkisi söz konusudur. Yine aynı şekilde uzun dönem analizinde KKB yani kamu kesimi büyüklüğünden diğer değişkenlere doğru nedensellik ilişkisinin olduğu görülmüştür. Bu durumda diğer değişkenler yani büyüme, nüfus değişimi ve vergi gelirlerinin esnekliği birer bağımsız değişken olarak kamu kesimi büyüklüğünü etkilemektedir. Yani uzun dönemde ekonomik büyüme kamu harcamalarının hasıla içindeki payını artırmaktadır, Ayrıca nüfus değişimi de benzer şekilde uzun dönemde kamu kesimini genişletmektedir. Türkiye'de gerek kısa gerekse uzun dönemde büyüme, nüfus değişimi birer bağımsız değişken olarak kamu kesimi büyüklüğünü etkilemektedir. Uzun dönemde büyüme ve nüfus değişimi yanında vergi gelirlerinin esnekliğinin de kamu kesimi büyüklüğünü etkilediği gözlenmiştir.

Kısa dönem sonuçlara bakıldığında ise, ele alınan dönem itibariyle Türkiye'de nüfus değişimi hem devletin büyümesi yani kamu harcamalarının artmasını hem de ekonomik büyümeyi etkilemektedir ve bu etki pozitif yönlüdür. Nüfus değişimi arttıkça devletin daha 
fazla harcama yapması söz konusu olmaktadır ayrıca literatürde de nüfus artışı kamu harcamalarını artıran nedenler arasında yer almaktadır. Bununla birlikte Türkiye'de nüfus değişimi büyümeyi de olumlu yönde etkilemiş ve ekonomik büyüme de kamu harcamalarını pozitif yönde etkilemiştir. Bu sonuç Türkiye'de bir anlamda Wagner Yasasının geçerli olduğunu ortaya koymuştur. Çünkü kamu harcamaları payındaki artışın ekonomik gelişmeyle birlikte arttı̆̆ tespit edilmiştir.

\section{Kaynaklar}

Acar, M. (2010), "Serbest Ticaret, Ekonomik Özgürlükler ve Refah”, Ahmet Yesevi Üniversitesi, Bilig Türk Dünyast Sosyal Bilimler Dergisi, 53, 1-28.

Acheson, J. et al. (2017), "Income Tax Revenue Elasticities in Ireland: An Analytical Approach", The Economic and Social Research Institute Research Series: Dublin, No: 59.

Adejare, A.D. \& S. S. Akande (2017), "The Impact of Personal Income Tax on Government Expenditure in Oyo State", Journal of Account and Financial Management, 2(4), 635643.

Boschi, M. \& S. d'Addona (2019), "The Stability of Tax elasticities Over the Business Cycle in European Countries", CAMA Working Paper, 44, 1-43.

Craig, E.D. \& A.J. Heins (1980), "The Effect of Tax Elasticity on Public Spending”, Public Choice, 33, 267-275.

Debasis, P. \& Y. Venkat (2018), “Assessing the Effects of Tax Elasticity on Government Spending”, International Journal of Engeering and Management Research, 8(5), 70- 76.

Dilorenzo, T.J. (1982), "Tax Elasticity and the Growth of Local Public Expenditure”, Public Finance Quarterly, 10(3), 385-392.

Dollery, B.E. \& A.C. Worthington (1995), "State Expenditure and Fiscal Illusion in Australia: A Test of the Revenue Complexity, Revenue Elasticity and Flypaper Hypotheses", Economic Analysis and Policy, 25(2), 125-140.

Erden-Özsoy, C. \& B.T. Tosunoğlu (2017), “GSYH'nin Ötesi: Ekonomik Gelişmenin Ölçümünde Alternatif Metrikler”, Ç.Ü. Sosyal Bilimler Enstitüsü Dergisi, 26(1), 285-301.

Ertekin, Ş. (2020), “Türkiye’de Kamu Kesimindeki Büyümenin İşsizlik Üzerindeki Etkisi: 1980 Sonras1 Dönem Analizi”, İzmir İktisat Dergisi, 35(1), 141-154.

Gelir İdaresi Başkanlığı, <https://gib.gov.tr/yardim-ve-kaynaklar/istatistikler>, 15.02.2021.

Gujarati, D.N. (1999), Temel Ekonometri, (Çev. Ü. Şenesen \& G.G. Şenesen), İstanbul: Literatür Yayınlar1.

Güler, A. \& C. Karaca (2017), “Türkiye'de Etkin Bir Vergi Sisteminin Kurulmasına İlişkin Politika Önerileri”, içinde: Scientific Cooperation for the Future in Economics and Administrative Sciences International Conference, 6-8 September, Greece, 165-177.

Güler, H. (2017), "Ücretlilerden Kesilen Gelir Vergisinin Türk Vergi Sistemi Üzerindeki İstikrar Etkisi”, Aksaray Üniversitesi İktisadi ve İdari Bilimler Fakültesi Dergisi, 9(4), 161-168.

Haughton, J. (1998), "Estimasting Tax Buoyancy, Elasticity and Stability”, Eager/PSGE- Excise Project Methodological Note, 1, 1-8.

Havranek, T. et al. (2016), "Dynamic Elasticities of Tax Revenue: Evidence From the Czech Republic", Applied Economics, 48(60), 5866-5881. 
Hazine ve Maliye Bakanlığ1 Muhasebat Genel Müdürlüğü, <https://muhasebat.hmb.gov.tr/merkeziyonetim-butce-istatistikleri>, 15.02.2021.

Kirmanoğlu, H. (2014), Kamu Ekonomisi, İstanbul: Beta Yayınları.

Kutbay, H. \& E. Aksoy (2020), "Vergi Esnekliğinin Kamu Harcamaları Üzerindeki Etkisi: Seçili OECD Ülkeler İçin Panel Veri Analizi”, Fiscaoeconomia, 4(3), 580-594.

Mansfield, C.Y. (1972), "Elasticity and Buoyancy of a Tax System: A Method Applied to Paraguay", IMF Staff Paper, 19(2), 425-446.

Misiolek, W.S. \& H.W. Elder, (1988), "Tax Structure and the Size of Government: An Empirical Analysis of the Fiscal Illusion and Fiscal Stress Arguments", Public Choice, 57, 233-245.

OECD (N/A), <https://stats.oecd.org/Index.aspx?DataSetCode=NAAG\#>, 15.02.2021.

Patnaik, D. \& V. Yaji (2018), “Assessing the Effects of Tax Elasticity on Government Spending”, International Journal of Engineering and Management Research, 8(5), 70-76.

Sandalc1, U. \& İ. Sandalc1, (2016), "Kamu Kesimi Ekonomik Büyüklüğü ve Kamu Etkinlik Düzeyi İlişkisi”, Pamukkale Üniversitesi Sosyal Bilimler Enstitüsü Dergisi, 25(1), 413-429.

Sevüktekin, M. \& M. Nargeleçekenler (2010), Ekonometrik Zaman Serileri Analizi, Nobel Yayın Dağıtım, 3. Baskı, Ankara.

Terzi, H. (1998), "Kamu Harcamaları ve Ekonomik Kalkınma İlişkisi Üzerine Ekonometrik Bir İnceleme", İsletme Finans Dergisi, Ocak, 67-78.

Wolswjik, G. (2007), "Short- and Long-Run Tax Elasticities The Case of The Netherlands", European Central Bank Working Paper Series, No: 763, 1-41.

Yamak, N. \& Y. Küçükkale (1997), “Türkiye'de Kamu Harcamaları Ekonomik Büyüme İlişkisi”, İsletme ve Finans Dergisi, 12(131), 5-14.

Yılancı, V. vd. (2020), “Türkiye'de Kamu Harcamaları ile Vergi Gelirleri Arasındaki İlişki: Frekans Alanda Asimetrik Testinden Kantlar”, Sayıştay Dergisi, 31(116), 121-139. 
Gürler-Hazman, G. \& P.B. Kaya (2022), "Türkiye'de Vergi Esnekliği ve Kamu Kesimi Büyüklüğü İlișkisi”, Sosyoekonomi, 30(51), 389-405. 